\title{
Turnover Intention and Behavior Organizational Citizenship on Indonesian Hospital Case
}

\author{
Rina Susanti, Hasyim, and Kemala Rita
}

\begin{abstract}
Since the last 4 years the nurse turnover rate on Indonesian Hospital Case has shown an increase and reached the highest number $(\mathbf{2 0 . 8 \%})$ in 2019 for contract nurses. If not anticipated it will disrupt the quality of service and reduce hospital performance. The high turnover rate also causes hospitals to incur additional costs for recruitment and training. Meanwhile, hospitals also need a lot of time to make nurses have the skills to provide quality care and meet the Patient Safety rules. The purpose of this study was to identify the influence of job satisfaction and organizational citizenship behavior on nurse turnover intention in hospital industry.

This study uses quantitative methods, to determine the causality relationship between related variables. Data processing is done quantitatively using SEM statistical test methods, to prove the hypothesis. The research sample was saturated with 282 nurses, both organic and contract, conducted since November 2019 until January 2020. Data processing is done quantitatively using the SEM statistical test method, to prove the hypothesis. Research findings: increasing OCB is an important thing to do by Indonesian Hospital Case management, because OCB is proven to increase the effect of job satisfaction in order to reduce nurse turnover intention. The voluntary attitude of nurses is the lowest $O C B$ behavior in contract and organic nurses, so efforts are needed to improve voluntary behavior so that nurse turnover intention can be significantly increased.

The results showed nurse turnover Intention was influenced by Job Satisfaction and OCB. The indirect effect through $\mathrm{OCB}$ is $\mathbf{1 . 4 3}$ times greater than the direct effect of Job Satisfaction on Turnover Intention. Perceptions of turnover intention for contract nurses are moderate, organic is low, job satisfaction is moderate (organic nurses are more satisfied than contract nurses), and OCB is high (organic nurses are higher than contract nurses).
\end{abstract}

Index Terms - Nurse Turnover Intention, Job Satisfaction and Organizational Citizenship Behavior.

\section{INTRODUCTION}

Human resources are an important factor in the hospital in building and forming the organization, because the hospital as an institution that produces products in the form of services, the HR element plays an important role in all activities in the hospital.

Excessive turnover of health workers, especially nurses, if

Published on July 25, 2020

Rina Susanti, Magister Administrasi Rumah Sakit Universitas Esa Unggul, Indonesia.

(corresponding e-mail: rinasusantidr@gmail.com)

Hasyim, Magister Administrasi Rumah Sakit Universitas Esa Unggul, Indonesia.

(e-mail: hasyim.ahmad@esaunggul.ac.id)

Kemala Rita, Magister Administrasi Rumah Sakit Universitas Esa Unggul, Indonesia.

(e-mail: kemalarita ${ }^{@}$ gmail.com). not anticipated will disrupt the quality of service to patients which in turn can reduce the performance of a hospital. Because a shortage of nurses can disrupt patient services on an ongoing basis, [26]. Because it becomes a management need to develop programs and strategies to retain nurses [10].

In addition, the high turnover rate also causes organizations to incur additional costs for recruitment to get workers ready to use. Preparing nurses who have the skills to provide quality care and meet patient safety rules also requires considerable time. In an effort to reduce the occurrence of employee turnover, it must start from efforts to reduce the desire to leave (turnover intetntion / TOI).

Indonesian Hospital Case as one of the private hospitals in industryial city which is trying to develop its services by adding some service capacity, also needs to evaluate nurses turnover rates especially in the last four years, the number of nurses leaving is always greater than the number of nurses entering, Nurse turnovers are experiencing a trend Significant improvement in 2019 especially for contract nurses reached $20.8 \%$ [27]

From the results of a preliminary survey conducted, there is a level of job satisfaction of nurses on Indonesian Hospital Case around sixty-seven percent (67\%), it is estimated that for contract nurses reaching below organic employees. Some factors that cause other than the amount of income that is still not full is also due to career development opportunities is one of the causes of reducing the level of job satisfaction. In addition, some previous studies still show different results for the influence of OCB on turnover intention. As an effort to anticipate and as a basis for appropriate improvement for management it is deemed necessary to examine the extent of the influence of Job Satisfaction and OCB for nurses turnover in Hospital industry.

The purpose of this study was to determine the effect of job satisfaction on nurse turnover intention and organizational citizenship behavior as an intervening variable in Hospital industry.

The research contribution is as input for Hospital industry management to try to reduce the nurse turnover rate, as well as an evaluation tool for in Hospital Industry management policies.

\section{Methods}

This research uses quantitative methods to see the causality relationship between endogenous / dependent variable turnover intention (Y) with exogenous / independent variable job satisfaction (X1) and exogenous / intervening variable organizational citizenship behavior / 
OCB (X2). Latent variables will be translated into manives variables in the form of quantitative primary data through questionnaires.

Source of data collected in this study came from questionnaires from 282 saturated samples of all contract nurses and organic in Hospital Industry.

\section{DATA ANALYSIS}

The survey results are expected to obtain valid and reliable data variables manives that will describe the latent variables studied so that it is possible to describe or describe the conditions of each research variable. Furthermore, quantitative data processing will be done using SEM statistical test methods with AMOS software to determine the influence of one variable with another variable.

Data collection techniques: Description of the variables used to determine the answers of respondents. The number of respondents 'answers starting from number 1 for a minimum and maximum is 5. To get the tendency of respondents' answers to each variable, it will be based on the average score (index) categorized into the range of scores based on the calculation of the three boxed method [5].

Upper limit on the range of scores: (\% F x 5); if all respondents answered 5. Lower limit of score range: (\% $\mathrm{F} \mathrm{x}$ 1 ); if all respondents answered 1 . With $\% \mathrm{~F}$ : is the frequency of each respondent's answer to each question.

\section{A. Research Hyphotesis}

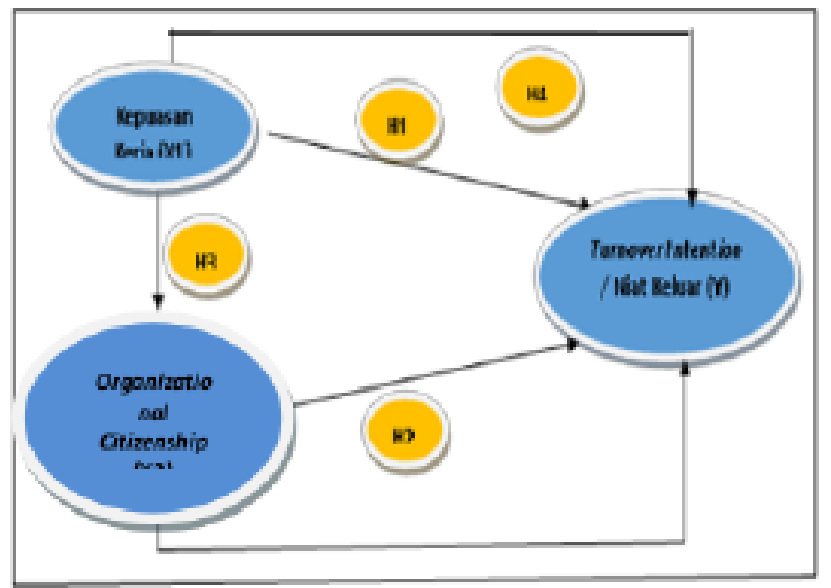

Fig. 1. Research Hypothesis.

\section{B. Research Model}

Research Model Design, shows that the Turnover Intention (TO) variable as a dependent latent variable has five indicators manives namely Y1 (thinking out of work), Y2 (Intending to look for work as an alternative), Y3 (intending to quit the job), Y4 (compatibility work with personal), and Y5 (matching income with work). The latent variable Job Satisfaction (KK) is an independent variable, by having 5 (five) manives variables, namely X1 (satisfying work), X2 (promotion opportunity), X3 (supportive supervisor's attitude), X4 (pleasant colleague attitude ), and X5 (supportive work environment). Organizational Citizenship Behavior (OCB) is a latent free intervening variable, has 5 (five) indicators of manives, namely: altruism/ helping attitude (X6), Conscientiousness/ voluntary (X7), Sportmanship/ tolerance (X8), Courtessy / respect (X9) ) and Civic virtue / attitude of responsibility (X10). Each of these indicators is described in the instrument and outlined in the form of a questionnaire that will be submitted to the respondent, the results obtained will be processed to obtain the average number of respondents' answers as the acquisition of the variable numbers manives of each of the three latent variables.

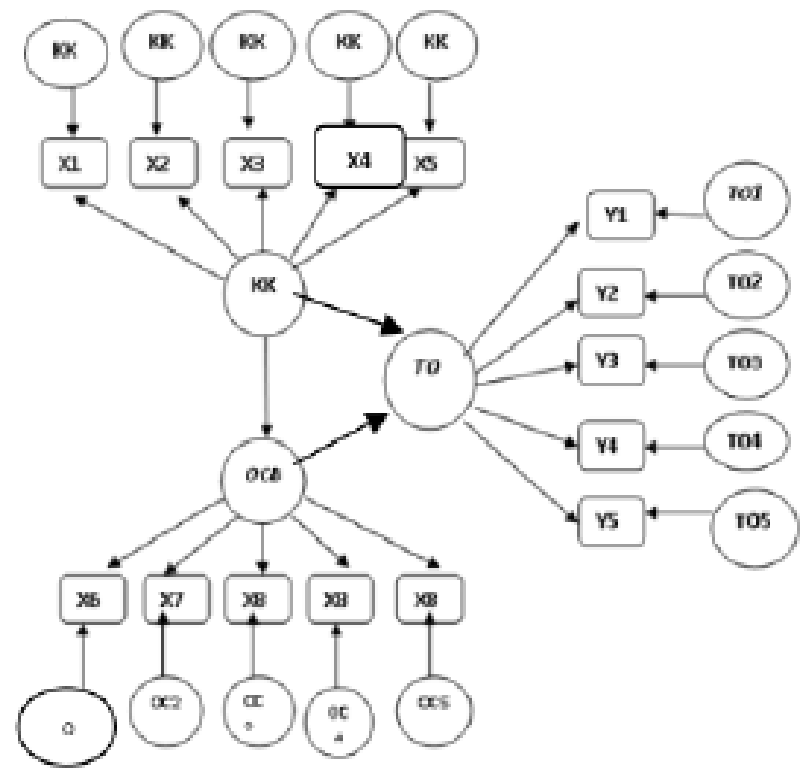

Fig.1. Reseach Model.

\section{RESUlt AND DisCUSSION}

\section{A. Instrument Testing}

Validity and reliability tests were performed on all three research variables.

TABLE 1: TOI, KK \& OCB RELIABILITY TEST
\begin{tabular}{|l|c|c|}
\hline $\begin{array}{c}\text { Variabel } \\
\text { Laten }\end{array}$ & CR & VE \\
\hline TOI & 0,969 & 0,679 \\
\hline KK & 0,959 & 0,617 \\
\hline OCB & 0,965 & 0,649 \\
\hline
\end{tabular}

Tables 1 show that the loading factor $(\lambda)$ value for each manifest variable is greater than 0.5 . This means that each manifest variable is declared valid in forming an exogenous construct.

Then the value of CR (construct reliability) must be above 0.7 and VE (variance extracted) must be above 0.5 already fulfilled so that it can be concluded that all exogenous constructs have good construct validity and reliability.

\section{B. Goodness of Fit Analysis}

The Goodness of fit criteria of the structural equation model above is presented in the following table: 


\begin{tabular}{|c|l|l|l|l|}
\hline No. & $\begin{array}{c}\text { Goodness } \\
\text { of Fit } \\
\text { Index }\end{array}$ & Cut-off Value & Hasil & Kesimpulan \\
\hline 1 & CMIN/DF & $\begin{array}{l}\text { Diharapkan Kecil } \\
(<)\end{array}$ & 1,986 & Good Fit \\
\hline 2 & RMSEA & $\leq 0,08$ & 0,059 & Good Fit \\
\hline 3 & GFI & $0,8 \leq \mathrm{GFI} \geq 0,9$ & 0,889 & Marg inal Fit \\
\hline 4 & A GFI & $0,8 \leq \mathrm{A} \mathrm{GFI} \geq 0,9$ & 0,850 & Marg inal Fit \\
\hline 6 & NFI & $0,8 \leq \mathrm{NFI} \geq 0,9$ & 0,866 & Marg inal Fit \\
\hline 7 & IFI & $0,8 \leq \mathrm{IFI} \geq 0,9$ & 0,945 & Good Fit \\
\hline 8 & TLI & $0,8 \leq \mathrm{TLI} \geq 0,9$ & 0,937 & Good Fit \\
\hline 9 & CFI & $0,8 \leq \mathrm{CFI} \geq 0,9$ & 0.944 & Good Fit \\
\hline
\end{tabular}

Overall good goodness of fit, Hair (1995) in (Wijanto, 2008).

\section{Structural Model Analysis}

\begin{tabular}{|c|c|c|c|}
\hline Pengaruh & Direct & Indirect & Total \\
\hline KK--> TOI & $-0,274$ & $\begin{array}{c}=0,573 \times(-0,655)= \\
0,375\end{array}$ & $-0,649$ \\
\hline
\end{tabular}

Based on Table 3 the direct effect of Job Satisfaction (KK) on Turnover Intention (TOI) is $(-0,274)$, while the effect of Job Satisfaction on Turnover Intention indirectly / through OCB as intervening is $(-0.375)$ in other words the indirect effect is greater (1.43 times greater), than direct effect. The total effect of $(-0,649)$, means there are still other factors of $-0,351$. Other possible causes such as labor market conditions, alternative opportunities, and the length of work are important obstacles to leaving existing jobs (S. P. et al Robbins, 2013).

\section{Hypothesis Testing Analysis}

TABEL 4: HYPOTHESIS TESTING

\begin{tabular}{|c|c|c|c|c|c|}
\hline & Hipotesis & thitung & $\mathrm{t}$ tabel & Signifikan & Keterangan \\
\hline H1 & $\begin{array}{l}\text { KepunsanK erja berpenganh } \\
\text { negatif terhadap TO }\end{array}$ & 10,394 & 1,971 & $(+)$ & $\mathrm{Hl}$ diterima \\
\hline H2 & $\begin{array}{l}\text { OCB berpenganuhnegatif } \\
\text { terhadap TO }\end{array}$ & $-5,955$ & $-1,971$ & $(+)$ & H2 diterima \\
\hline H3 & $\begin{array}{l}\text { KepunsanK erja berpenganh } \\
\text { positif terhadap OCB }\end{array}$ & 10,510 & 1,971 & $(+)$ & H3 diterima \\
\hline H4 & $\begin{array}{l}\text { Kepunsan Kerja berpenganuh } \\
\text { negatif dan signifik an terhadap } \\
\text { TOI, melahi OCB sebagai } \\
\text { intervering }\end{array}$ & $-8,011$ & $-1,971$ & $(+)$ & H4 diterima \\
\hline
\end{tabular}

\section{E. Description of Three Box Method Result}

\section{Turnover Intention}

The result of the perception of contract nurses on the variable turnover intention is at a moderate level, but at the organic nurse is at a low level. For the highest dimension of turnover intention the organic nurse and contract are the intention to leave due to the incompatibility of work with income / economic dimension (moderate). The highest indicator is diferent in organic nurses TO5.3 "I feel the incentives I get do not correspond to the amount / burden of my work" while the contract nurses in TO3.2 "I will get out of this hospital if there is a better opportunity" (moderate). This shows that contract nurses have a higher exit potential than organic nurses, with the main cause of income mismatch problems.

\begin{tabular}{|c|l|c|c|}
\hline $\begin{array}{c}\text { Kode } \\
\text { Dimensi }\end{array}$ & \multicolumn{1}{|c|}{ DABLensi (Indikator Manives) } & Organik & Kontrak \\
\hline \hline TOI1 & Berfikir keluar dari pekerjaan & Rendah & Sedang \\
\hline TOI2 & $\begin{array}{l}\text { berniat mencari pekerjaan sebagai } \\
\text { alternatif }\end{array}$ & Rendah & Sedang \\
\hline TOI3 & Berniat keluar dari pekerjaan & Rendah & Sedang \\
\hline TOI4 & $\begin{array}{l}\text { Niat keluar karena kecocokan } \\
\text { pekerjaan dengan karakteristik } \\
\text { individu (Dimensi Psikologis) }\end{array}$ & Rendah & Rendah \\
\hline TOI5 & $\begin{array}{l}\text { Niat keluar karena kecocokan } \\
\text { pendapatan (Dimensi Ekonmi) }\end{array}$ & Sedang & Sedang \\
\hline Y & Turn over intention & Rendah & Sedang \\
\hline
\end{tabular}

\begin{tabular}{|c|c|c|c|}
\hline Kode & Perawat Organik & Kriteria & Kriteria \\
\hline TO 5.3 & $\begin{array}{l}\text { Saya merasa insentif yang saya } \\
\text { peroleh tidak sesuai dengan } \\
\text { banyaknya/beban peker jaan saya }\end{array}$ & 606 & Sedang \\
\hline TO 2.2 & $\begin{array}{l}\text { Saya sudah menyampaikan beberapa } \\
\text { lamaran peker jaan ke tempat lain }\end{array}$ & 398 & Rendah \\
\hline Kode & Perawat Organik & Kriteria & Kriteria \\
\hline TO 3.2 & $\begin{array}{l}\text { Saya akan keluar dari rumah sakit ini } \\
\text { jika ada kesempatan yang lebih baik }\end{array}$ & 231 & Sedang \\
\hline TO 2.2 & $\begin{array}{l}\text { Saya sudah menyampaikan beberapa } \\
\text { lamaran peker jaan ke tempat lain }\end{array}$ & 143 & Rendah \\
\hline TO 4.3 & $\begin{array}{l}\text { Saya merasa pekerjaan saya tidak } \\
\text { sesuai dengan kepribadian saya }\end{array}$ & 143 & Rendah \\
\hline
\end{tabular}

\section{Job Satisfaction}

\begin{tabular}{|c|l|c|l|c|l|}
\hline \multicolumn{7}{|c}{ TABLE 7: KK DIMENSION } \\
Kode & Indikator Manives (Dimensi) & $\Sigma$ & Kriteria & $\Sigma$ & Kriteria \\
\cline { 3 - 6 } & & \multicolumn{2}{|c|}{ Organik } & \multicolumn{2}{|c|}{ Kontrak } \\
\hline \hline X1 & Pekerjaan yang memuaskan & 719 & Sedang & 219 & Sedang \\
\hline X2 & Peluang Promosi & 687 & Sedang & 216 & Sedang \\
\hline X3 & sikap atasan yang mendukung & 748 & Sedang & 248 & Sedang \\
\hline X4 & $\begin{array}{l}\text { Sikaprekan kerjaryang } \\
\text { menyenangkan }\end{array}$ & 836 & Tinggi & 257 & Tinggi \\
\hline X5 & $\begin{array}{l}\text { Lingkungan kerja yang } \\
\text { mendukung }\end{array}$ & 791 & Tinggi & 243 & Sedang \\
\hline X1 & Rerata Kepuas an Kerja & 756 & Sedang & 236 & Sedang \\
\hline
\end{tabular}

Organic nurse job satisfaction index and contract are the same (medium), with higher organic nurse satisfaction level (organic nurse job satisfaction gets a high index of $40 \%$, while contract nurses are only 27\%). The lowest job satisfaction is the same, namely the opportunity for promotion (medium). But different results on the lowest type of statement on organic nurses, KK 1.2 "I am satisfied with the nurses career path rules that are currently applied" for contract nurses lowest statement: KK 1.3 "I am satisfied with the opportunity to participate in training outside the 
hospital (low). This can make a different basis for improvement for each group of nurses.

TABLE 8: KK INDICATOR

\begin{tabular}{|c|c|c|c|}
\hline Kode & Peraw at Organik & Indeks & Kriteria \\
\hline KK1.2 & $\begin{array}{l}\text { Saya puas dg peraturan jenjang } \\
\text { karir perawat yg diterapkan } \\
\text { saat ini }\end{array}$ & 645 & Sedang \\
\hline KK4.2 & $\begin{array}{l}\text { Saya puas dg sikap rekan kerja } \\
\text { saya yg ramah }\end{array}$ & 840 & Tinggi \\
\hline Kode & Perawat Koontrak & Indeks & Kriteria \\
\hline KK1.3 & $\begin{array}{l}\text { Saya puas dengan kesempatan } \\
\text { mengikuti pelatihan di luar rumah } \\
\text { sakit }\end{array}$ & 204 & Sedang \\
\hline KK4.1 & $\begin{array}{l}\text { Saya puas dengan sikap rekan } \\
\text { saya yang kooperatif/suka } \\
\text { bekerja sama }\end{array}$ & 258 & Tinggi \\
\hline
\end{tabular}

3. Organizational Citizenship Behavior

TABLE 9: OCB DIMENSION

\begin{tabular}{|c|l|c|c|c|c|}
\hline \multirow{2}{*}{ Kode } & \multirow{2}{*}{ Indikator M anives } & \multicolumn{2}{|c|}{ Rerata } & \multicolumn{2}{c|}{ Rerata } \\
\cline { 3 - 7 } & & \multicolumn{2}{c|}{ Organik } & \multicolumn{2}{c|}{ Kontrak } \\
\hline \hline $\mathrm{X} 6$ & Alturism (skkap menolong) & 849 & Tinggi & 267 & Tinggi \\
\hline $\mathrm{X} 7$ & Conscietiosness (sukarela) & 763 & Sedang & 248 & Sedang \\
\hline $\mathrm{X} 8$ & Sportmanship (sikap & 846 & Tingg & 268 & Tinggi \\
\hline $\mathrm{X} 9$ & Courtessy (Sikap menghargai) & 849 & Tinggi & 269 & Tinggi \\
\hline $\mathrm{X} 10$ & $\begin{array}{l}\text { C'́vic Virtuew (sikap tanggung } \\
\text { jawab) }\end{array}$ & 815 & Tinggi & 262 & Tinggi \\
\hline $\mathrm{X} 2$ & OCB & 824 & Tinggi & 263 & Tinggi \\
\hline
\end{tabular}

TABLE 10: OCB INDICATOR

\begin{tabular}{|c|l|c|c|}
\hline Kode & \multicolumn{1}{|c|}{ Pernyataan } & Indeks & Kriteria \\
\hline \hline OCB2.3 & $\begin{array}{l}\text { Saya tidak keberatan hadir ke tempat } \\
\text { kerja dihar jam kerja tanpa dinitung } \\
\text { lembur, untuk melakukan kegiatan } \\
\text { positif diluar uraian tugas/kewajiban }\end{array}$ & 726 & Sedang \\
\hline OCB4.1 & $\begin{array}{l}\text { Saya menghargai rekan kerja saya } \\
\text { dengan cara menjaga hubungan baik }\end{array}$ & 884 & Tinggi \\
\hline Kode & $\begin{array}{l}\text { Pernyataan } \\
\text { OCB2.3 tidak keberatan hadir ke tempat } \\
\text { kerja dihar jam kerja tanpa dihitung } \\
\text { lembur, untuk melakukan kegiatan } \\
\text { positif diluar uraian tugas/kewajiban }\end{array}$ & 233 & Sedang \\
\hline OCB1.1 & $\begin{array}{l}\text { Saya sering menolong rekan kerja yg } \\
\text { mengalami kesulitan masalah }\end{array}$ & 281 & Tinggi \\
\hline
\end{tabular}

\section{DISCUSSION}

In Table 7 shows the results of hypotheses 1, 2, 3 and 4 can be accepted.

Based on the three box method, the nurse nurses' perception of turnover intention variables is in the medium criteria, but in the organic nurses the criteria are low. Based on the results of calculations in Table 12 shows that the value of $t$ count $>t$ table, namely $(-5,955)>(-1,971)$, this means that the variable Job Satisfaction (KK) negatively affects Turnover Intention (TOI), meaning that if Turnover Intention will be lowered then the level of Job Satisfaction must be increased (Hypothesis 1: accepted).

Based on the calculation results in Table 4.22 shows that the value of $t$ count $>t$ table, namely $(-10,510)>(-1,971)$, this means that the Organizational Citizenship Behavior (OCB) variable negatively influences turnover intention (TOI), meaning that if turnover intention will be reduced then the level of Organizational Citizenship Behavior must be increased (Hypothesis 2: accepted).

Based on the calculation results in Table 4.22 shows that the value of $t$ count $>t$ table (10.394> 1.971), this means that Job Satisfaction has a positive effect on Organizational Citizenship Behavior, meaning that if Organizational Citizenship Behavior will be increased, Job Satisfaction must be increased (Hypothesis 3: accepted ).

Based on the calculation results obtained $t$ value for testing the effect of mediation on this hypothesis is $-8,011$. If $\alpha=0.05$, then $\mathrm{t}$ table $=-1.971$. From these calculations it can be concluded that $\mathrm{t}$ arithmetic $(-8,011)>\mathrm{t}$ table $(-1,971)$ with a significance level of 0.05 , it can be concluded that Organizational citizenship behavior is capable of intervening between Job Satisfaction and Turnover Intention. This type of mediation is partial mediation (part mediation), meaning that whether or not there is OCB, job satisfaction still has a significant effect on turnover intention but the indirect effect through OCB is greater than the direct effect. In other words, OCB is able to increase the effect of job satisfaction on turnover intention. This type of mediation is partial mediation (part mediation), meaning that whether or not there is OCB, job satisfaction still has a significant effect on turnover intention but the indirect effect through OCB is greater than the direct effect. In other words, OCB is able to increase the effect of job satisfaction on turnover intention (Hypothesis 4: accepted).

An increase in job satisfaction can further reduce nurse turnover intention in line with research conducted by [28] that Job Satisfaction is a positive perception of work based on factors contained in the work environment such as supervisor style, policies and procedures, work group affiliation, working conditions and other benefits for workers, will make nurses feel comfortable and loyal to the company, on the contrary it will have a negative impact on the desire to leave the company (turnover intention). Nurses who are accustomed to doing OCB behavior (willing to do work that is not their responsibility / duty voluntarily) usually occur in nurses who are comfortable at work and tend to be loyal, of course logically loyal nurses will not have the intention to leave the company (turnover intention ) [16].

The results of this study are consistent with research conducted by [2] conducted at Roemani Muhamadiyah Hospital Semarang, research conducted by [11] of PT Pertamedika employees, and research conducted by [16] at Besakih Beach Hotel, with the same result is proven that job satisfaction has a negative and significant effect on turnover intention. This hypothesis is in accordance with research conducted by [17], on the employees of PT Kediri Matahari Corn Mills with the result that there is a significant negative effect of OCB on employee turnover intention. 


\section{FINDING}

Improving Organizational Citizenship Behavior (OCB) is an important thing to do by Indonesian Hospital Case management, because OCB is proven to be able to increase the effect of job satisfaction in order to reduce nurse turnover intention. The voluntary attitude of nurses is the lowest OCB behavior in both organic and contract nurses, so efforts are needed to improve voluntary behavior so that nurse turnover intention can be significantly increased.

\section{CONCLUSION}

There is a significant negative effect of job satisfaction on nurses turnover intention in Hospital Industry, so to increase the desire to leave it needs to be made efforts to increase job satisfaction for nurses

There is a significant positive effect of job satisfaction on organizational organizational citizenship behavior of nurses in Hospital Industry, so to improve the achievement of OCB it is necessary to make improvements to improve job satisfaction for nurses.

There is a significant negative effect of organizational citizenship behavior on nurses turnover intention in Hospital Industry, so to reduce turnover intention efforts need to be made to increase OCB achievements again

There is a significant negative effect between job satisfaction on turnover intention and organizational citizenship behavior as intervening nurses in Hospital Industry. The indirect effect through OCB is 1.43 times greater than the direct effect of Job Satisfaction on Turnover Intention. So that Hospital Industry Case management to reduce the desire to leave nurses will be more meaningful to make efforts to improve OCB, rather than just making efforts. efforts to increase job satisfaction, so that repairs should be done in parallel from all sides both for increasing OCB and job satisfaction.

\section{IMPLICATION}

A first priority for Hospital Industry management is to make efforts that can improve organizational citizenship behavior, such as : such as instilling a commitment to always apply empathy to coworkers, promote teamwork, develop a caring attitude to help colleagues in both work and personal problems, in each morning briefing activity before carrying out activities in the service unit by each Unit Head. Management representatives periodically convey the condition of the company at the monthly meeting of the nursing service unit so that nurses can get to know the condition of the hospital including the difficulties that are being experienced, so as to grow tolerant to the conditions that are not yet ideal from Hospital Industry by developing a positive attitude that is conveying an attitude not agree with a good attitude so that it does not damage the work climate, and it is hoped that getting to know the company's constituency can increase ownership and loyalty to hospitals so that they are more willing and willing to do positive things for the company outside of working hours until they are willing to not count overtime if indeed needed according to the situation and condition of the company. Also, through activities such as capacity building between employees so as to further accelerate awareness to implement OCB behavior through games made by expert staff. Program ESQ-type training, routine recitation for employees at the Hospital Anniversary event or the Day of Religious Affairs for those who are Muslims in the Hospital industry mosque, so that employees can be more sincere to improve OCB behavior.

In addition, in order to reduce nurse turnover intention, it is also necessary to immediately make improvements by Hospital Industry management in order to increase nurse job satisfaction, including conducting comparative studies on the application of nurses' career paths to hospitals that have implemented relatively ideal career paths, as management considerations to compile decree Team and Work Guidelines for Nurse Career Level Compilation Team.

Evaluate the length of service for contract nurses. Hospital Industry management can review and evaluate the length of service of contract nurses which up to 3 (three) years have been shorter, if possible can refer to labour regulations for only a year, then can be evaluated and assessed whether it can be processed into organic employees or terminated if not according to company criteria, so that contract nurses can freely look for job opportunities elsewhere. By shortening the contract period, benefits as organic employees can be immediately received by contract nurses, so that it can quickly increase job satisfaction of contract nurses.

\section{RECOMENDATION}

\section{For the management of the Hospital Industry}

Hospital Industry Management can immediately form a Nurse Career Structuring Team through the formation of a Team SK signed by the Hospital Director, assigning a team consisting of management representatives (Head of Nursing, Manager of Medical and Nursing Services), Chair of the Nursing Committee, representatives of each senior nurse from the unit unit special units (Intensive Room nurses: ICU / ICCU, NICU / PICU, Operating Room Nurses, Advanced Hemodialysis Nurses, Pediatricians, Emergency Unit Nurses).

Hospital industry management can implement performance-based incentives for nurses in order to be able to accommodate the distribution of performance-based incentives for the nurse profession is related to the achievement of the target activities in the nurse logbook in accordance with the provisions of the career path that will be made by the Team

Hospital Industry can evaluate the length of service for contract nurses, management can review and evaluate the length of service of contract nurses which up to 3 (three) years have been shorter, if possible can refer to labor regulations for only one year, then can be evaluated and assessed whether it can be processed into organic employees or terminated if not according to company criteria, so that nurses can still freely look for work opportunities elsewhere.

Hospital Industry can improve contract nurse benefits If the condition of management has not been able to shorten the contract nurse's service life to be shorter in the near future (for example because financial conditions are not yet possible), policy improvements can be made for contract nurses, for example the provision of training out of the hospital can be given an opportunity for accomplished and 
loyal contract nurses ( an agreement is made if the certified training has departed and will not resign within a certain timeframe). Opportunities are involved in promotions, for contract nurses who meet vacant job criteria and are judged to be equal in quality and competence to contract nurses (hard and soft skills) as on par with other organic nurses / employees.

Hospital industry can hold a Leadership Training Program, conducting leadership leadership training programs in Nursing Services in accordance with their levels in order to improve leadership skills as a leader, both formally / informally. Especially, to develop the attitude / ability of empowering. Sharpen the leadership's ability to behave appropriately according to the conditions of the staff they lead, for example giving responsibility to be given the authority to make decisions, by previously providing important information about the objectives to be achieved from the tasks given to subordinates, asking subordinates to find solutions in completing certain tasks, support subordinates with various means and support the completion of tasks, guiding by providing constructive feedback, as well as making appropriate procedures to find out the issues and results achieved from the area of delegated responsibility. So, expect nurses' satisfaction in terms of the attitude of superiors who provide assistance in work and attitudes towards giving freedom in making decisions can be improved.

Hospital Industry management is expected to be able to evaluate the implementation of the promotion process to be more open / transparent: provide wider opportunities if there is information on promotional opportunities if it can be filled by nurses (fulfilling job qualifications), fair: selection based on work performance and objective capabilities. So that it will increase the perception of nurse satisfaction with the promotion process in Hospital Industry.

Hospital Indsutry management sets a time target, criteria for success and responsibility for each activity / program, so that regular evaluations can be carried out, and the entire program can immediately be felt by all nursing employees in particular and Hospital Industry management in general.

\section{For Further Researchers}

The results of this study are expected to be developed by subsequent researchers by adding at least one other variable that is thought to also affect turnover intention. In addition, it is also necessary to improve the questionnaire, as well as the selection of a more appropriate time in distributing the questionnaire.

\section{REFERENCES}

[1] Ajzeen, Fishbein, 1975. (1975). Theory of Reasoned Action. Encyclopedia of Management Theory. https://doi.org/10.4135/9781452276090.n292.

[2] Andini, R. (2006). Kepuasan Kerja, Komitmen Organisasional (Studi Kasus Pada Rumah Sakit Roemani Muhammadiyah Semarang ). 1112.

[3] Colquitt, J. (2013). Organizational behavior : improving performance and commitment in the workplace (J. A. LePine, Ed.). Boston: McGraw-Hill.

[4] Ferdinant, A. (2006). Metode Penelitian Management (lima).

[5] Irwandi, S. A. (2002). Analisis Pengaruh Job Insecurity Terhadap Turnover Intention. Jurnal Administrasi Bisnis. Retrieved from eprint.undip.ac.id.

[6] Kreitner, R., \& Kinicki, A. (2014). Organizational behavioral. Boston: McGraw-Hill.
[7] Lestari, P. et al. (2015). Pengaruh Kepuasan Kerja dan Komitmen Organisasi Terhadap Organizational Citizenship Behaviour (OCB) dengan Dukungan Organisasi sebagai Variabel ( Studi Pada Karyawan PT PLN ( Persero ) APJ Semarang ). 4, 1-15.

[8] Luthans, F. (2011). Organizational Behavior. In Hospital Administration (Twelfth https://doi.org/10.5005/jp/books/10358_23.

[9] Mobley, W. H., Griffeth, R. W., Hand, H. H., \& Meglino, B. M. (1979). Review and conceptual analysis of the employee turnover process. Psychological Bulletin, 86(3), 493-522. https://doi.org/10.1037/0033-2909.86.3.493.

[10] Mosadeghrad, M. A. (2013). Quality of Working Life and Turnover Intentions: Implications for Nursing Management. International Journal of Research in Nursing, 4(2), 47-54. https://doi.org/10.3844/ijrnsp.2013.47.54

[11] Nandini, N. et. al. (2019). Penyebab Turnover Intention Pasa Pegawai Instalasi Gizi Rumah Sakit PHC Surabaya. Journal of Chemical Information and Modeling, 53(9), 1689-1699.

[12] Nasurdin, A. M. et al. (2018). The relation between turnover intention, high performance work practices (HPWPS), and organisational commitment: A study among private hospital nurses in Malaysia. Asian Academy of Management Journal, 23(1), 23-51. https://doi.org/10.21315/aamj2018.23.1.2.

[13] Nelfianti, F. (2016). Pengaruh Organizational Citizenship Behavior,Komitmen Organisasional,dan Stress Kerja Terhadap Turnover Intention dengan Kepuasan Kerja (Studi Kasus: PT. Pertamina Bina Medika). Akademi Sekretari Dan Manajemen BSI Jakarta.

[14] Ningsih, Febru R, et al. (2014). Pengaruh Job Satisfaction terhadap OCB dan Turnover Intention. BENEFIT Jurnal Manajemen Dan Bisnis, 18(1), 41-48.

[15] Ningtyas, S. I. (2016). The Effect of Complexity in Organization and Job Involvement on Organizational Citizenship Behaviour (OCB) of Primary School Teachers in Duren Sawit Sub District. Research and Development Journal of Education, Vol.2 No. 2 April 2016, 2(2), 130.

[16] Pratama, I. G. B. et al. (2017). Organisasional Terhadap Organizational Citizenship Behavior. 6(7), 3570-3594.

[17] Robbins, S. P. et al. (2013). Organizaional Behavior (15th ed.). Pearson Education Ltd.

[18] Robbins, S. P. et al. (2016). Organizational Behavior (2016th ed; Lestari \& P. Puji, Eds.). Jakarta, Salemba Empat.

[19] Robbins, S. P., \& Judge, T. A. (2016). Organizational Behavior (2016(Pearson0, Ed.). Jakarta, Salemba Empat.

[20] Sugiyono. (2017). MetodePenelitian Kuantitatif, Kualitatif dan R\&D. Bandung: PT Alfabet. In Sugiyono. (2017). MetodePenelitian Kuantitatif, Kualitatif dan R\&D. Bandung: PT Alfabet. (Vol. 53). https://doi.org/10.1017/CBO9781107415324.004.

[21] Suhanto, E. (2009). Pengaruh Stres Kerja Dan Iklim Organisasi Terhadap Turnover Intention Dengan Kepuasan Kerja Sebagai Variabel Intervening. Jurnal Minds: Manajemen Ide Dan Inspirasi, 4(2), 93-105. https://doi.org/10.24252/minds.v4i2.4148.

[22] Udayana, I Putu Gd Paramita, et al. (2017). Pengaruh Kepuasan Kerja dan Komitmen Organisasional Terhadap Organisazional citizenship Behavior. E-Jurnal Manajemen Unud, Vol. 6, No. 7, 2017; 3570-3594.

[23] Widyasari, N. M. et al. (2017). Pengaruh Ketidakamanan Kerja dan Kompensasi Terhadap Kepuasan Kerja dan Turnover Intention Karyawan Besakih Beach Hotel Denpasar. E-Jurnal Ekonomi Dan Bisnis Unud 6.5 (2017):2103-2132. ISSN : 2337-3067.

[24] Wijanto, S. H. (2008). Structural Equation Modeling dengan Lisrel 8.8 (Pertama). Yogyakarta.

[25] Wonowijoyo, S. M. et al. (2019). Pengaruh Organizational Commitment dan Kepuasan Kerja Terhadap Turnover Intention di PT Kediri Matahari Corn Mills. Journal of Chemical Information and Modeling. AGORA Vol. 6, No,. I. (20180-1-9. https://doi.org/10.1017/CBO9781107415324.004.

[26] Laschinger et al (2006). Nurse Turnover : A Literatur Review. International Journal of Nursing Studies. Vol 43, February 2006, $p$ 237-263.

[27] Gillies, (1994). Nursing management: System approach. (3th ed), philadelpia: W. B. Saunders Co. Hastono Priyo (2007).

[28] Leitter et all (2011), The Impact of Civility Intervention on Employee Social Behavior, Distress, and Attitudes, in Journal of Applied Psychology 96(6):1258-74 · July 2011 with 3,759 Reads DOI: 10.1037/a0024442 - Source: PubMed. 